\title{
Penerapan Teknologi Silase dan Fermentasi untuk Ketahanan Pakan Ternak di Daerah Sub-optimal Rejosari-Bantul
}

\author{
Ari Diana Susanti ${ }^{1}$, Muhammad Cahyadi ${ }^{2}$, Paryanto $^{3}$, Fadilah $^{4}$ \\ Universitas Sebelas Maret ${ }^{1,2,3,4}$ \\ aridiana@staff.uns.ac.id ${ }^{1}$, mcahyadi@staff.uns.ac.id ${ }^{2}$, paryanto.uns@yahoo.com ${ }^{3}$, fadilah@staff.uns.ac.id ${ }^{4}$
}

\begin{abstract}
The availability of ruminant feed in terms of amount and nutritional adequacy is a common problem during the dry season. This condition is worst at the peak of the dry season (JulyOctober) such as that faced by the Kelompok Tani Rukun Binantu of Rejosari in Bantul RegencyYogyakarta. Pre-survey shows that the cost of feed in the dry season is uncompetitive to the price of cattle. This problem was solved by Program Kemitraan Masyarakat (PKM-UNS) 2020 with workshop in cattle feed preservation using silage and fermentation techniques. The silage technique is used in conventional-local forage, while the fermentation technique is aimed at preserving low-nutrient animal feed as well as improving digestibility and nutritional adequacy of the feed. Product's monitoring and evaluation are carried out after 7 days for fermentation technique and 21 days for silage technique. The program is success in solving of Mitra's problems and it is also one of Tri Dharma Perguruan Tinggi in technology transfer for rural communities.
\end{abstract}

Keywords: cattle feed; sub-critical areas; fermentation; ruminant, silage.

\begin{abstract}
Abstrak
Ketersediaan pakan ruminansia secara jumlah dan kecukupan nutrisi merupakan permasalahan umum petani-peternak pada musim kemarau. Kondisi ini semakin terasa pada puncak kemarau (Juli-Oktober) di daerah sub-kritis perbukitan seperti yang dihadapi Kelompok Tani Rukun Binantu Dusun Rejosari Kabupaten Bantul-Yogyakarta. Survei awal menunjukkan biaya pembelian pakan ternak di musim kemarau sangat tidak kompetitif terhadap harga ternak ruminansia sendiri yang cenderung turun. Problematika tersebut dipecahkan mitra bersama dengan Tim PKM UNS melalui Program Kemitraan Masyarakat 2020 dengan pelatihan pengawetan pakan ternak. Metode pengawetan yang digunakan adalah teknik silase dan teknik fermentasi. Teknik silase digunakan pada hijauan pakan konvensional-lokal dengan tiga variasi bahan tambahan, yaitu bekatul, tetes tebu, dan campuran bekatul-tetes tebu. Sedangkan teknik fermentasi menggunakan stimulator hasil penelitian UNS dan ditujukan untuk pengawetan pakan ternak minim nutrisi sekaligus untuk memperbaiki ketercernaan dan kecukupan nutrisi pakan. Keberhasilan program ini selain menyelesaikan permasalahan Mitra juga merupakan salah satu bentuk Tri Dharma Perguruan Tinggi.
\end{abstract}

Kata Kunci: daerah sub-kritis; fermentasi; pakan ternak; ruminansia; silase. 


\section{A. PENDAHULUAN}

Kontinyuitas pakan ternak sepanjang musim merupakan permasalahan umum yang dihadapai petani-peternak. Hal ini menjadi cukup krusial pada puncak musim kemarau (Juli-September) untuk daerah topografi perbukitan/pegunungan (subkritis) seperti warga RT 6 RW 32 Dusun Rejosari Desa Srimartani Kecamatan Piyungan Kabupaten Bantul Propinsi Yogyakarta yang tergabung dalam Kelompok Tani Rukun Binantu. Warga terpaksa memperluas area jelajah mencari rumput hingga wilayah Kalasan bahkan Kulon Progo tergantung daerah persawahan yang sedang musim panen dan membeli hijauan makanan ternak (HMT) dari daerah dataran rendah sekitar.
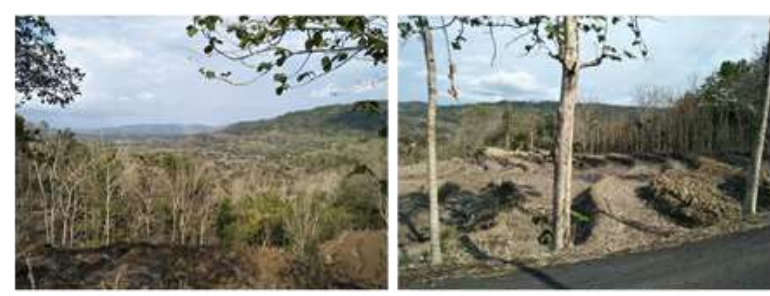

Gambar 1. Kondisi Wilayah Mitra pada Musim Kemarau (Foto Diambil Akhir Bulan Oktober 2019)

Kebutuhan pakan 2 ekor sapi per hari adalah 4 ikat rumput Kolonjono seharga Rp.20.000/ikat atau seikat jerami seharga Rp.50.000/ikat. Warga yang berkecukupan dapat membeli lamen (tangkai dan daun padi) dengan harga Rp.1.000.000/truk yang mencukupi untuk pakan 2 ekor sapi selama 1 bulan.

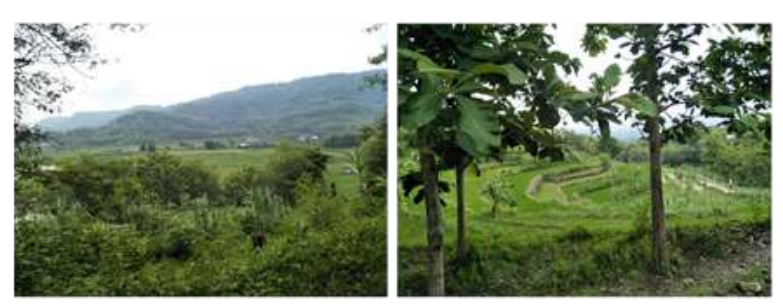

Gambar 2. Kondisi Wilayah Mitra pada Musim Penghujan (Foto Diambil Akhir Bulan Januari 2020)
Tingginya harga pakan di musim kemarau tidak sejalan dengan harga sapi. Saat musim kemarau harga sapi relatif turun dan menyulitkan posisi tawar peternak. Harga sapi dewasa berkisar Rp.10.000.000Rp.15.000.000/ekor di tingkat peternak. Peternak harus jeli apabila ingin mempertahankan ternak sapi hingga musim pakan murah dan harga normal kembali dengan memperhitungkan biaya pembelian pakan.

Tabel 1. Anggota Kelompok Tani Rukun Binantu dan Jumlah Kepemilikan Aktual Hewan Ternak Sapi per September 2020

\begin{tabular}{clc}
\hline No. & Nama Anggota & Jumlah Sapi \\
\hline 1 & Mujiyo & 2 \\
2 & Basiran & 3 \\
3 & Giyanto & 3 \\
4 & Sugeng & 4 \\
5 & Subarjo & 2 \\
6 & Kliwon & 4 \\
7 & Daliyo & 2 \\
8 & Ngadiran & 3 \\
9 & Budi & 2 \\
10 & Tarno & 2 \\
11 & Sardi & 2 \\
12 & Mugimin & 1 \\
\hline
\end{tabular}

Usaha yang telah dilakukan oleh anggota Kelompok Tani Rukun Binantu dalam menghadapi masa sulit pakan adalah dengan metode kering, yaitu dengan menjemur HMT hingga layu/kering dan menumpuknya di area kandang. Metode ini memiliki kelemahan dari segi volume (kuantitas) yang besar dengan potensi kehilangan kandungan nutrisi (kualitas). Tingginya kandungan serat kasar pada HMT kering berakibat pada daya cerna yang rendah (Amin et al., 2015; Bata, 2008; Lamid et al., 2013). Sehingga peternak akan menambahkan asupan nutrisi ternak sapi dengan polar/pelet pada pagi dan sore hari 
seharga Rp.192.000/sak $50 \mathrm{~kg}$ dan dapat mencukupi untuk 2 ekor sapi selama15 hari.

Berdasar wawancara awal, diperoleh informasi kegiatan kelompok tani mayoritas terkait dengan permasalahan pertanian dan belum membahas secara khusus terkait hewan ternak. Mitra juga belum memiliki kandang kelompok. Seluruh hewan ternak ditempatkan dalam kandang di dekat rumah masing-masing, bahkan ada yang berada dalam satu bangunan rumah dengan rumah peternak.
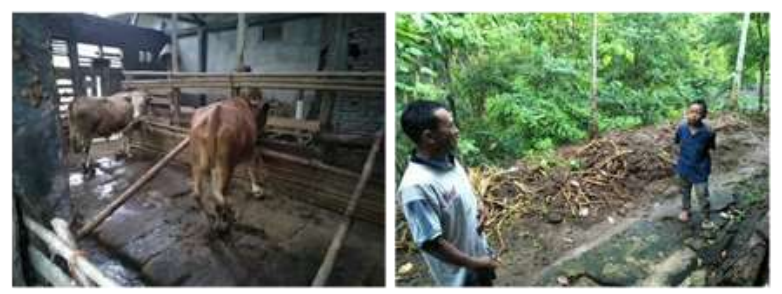

Gambar 3. Kondisi Kandang dan Sekitar Kandang Milik Salah Satu Anggota Kelompok Tani Rukun Binantu

Terkait dengan kotoran ternak, belum ada pemanfaatan sebagai sumber energi terbarukan (biogas). Peternak secara manual akan menumpuk kotoran ternak di dekat kandang agar menjadi kompos secara alamiah. Kotoran ternak yang telah menjadi kompos akan dibawa ke ladang sebagai pupuk kandang. Kotoran ternak yang masih baru tidak dapat digunakan sebagai pupuk karena masih mengandung biogas dan bersifat panas bagi tanaman. Proses pembentukan kompos ini secara jelas terlihat mengganggu sanitasi lingkungan karena bau dan lindi cairan kotoran sapi yang dibuang ke aliran anak sungai di dekat pemukiman.

Berdasar uraian di atas, permasalahan utama yang dihadapi Mitra dan ingin dicari solusinya bersama Tim Universitas Sebelas Maret melalui Program Kemitraan Masyarakat (PKM-UNS) 2020 adalah ketersediaan pakan ternak tanpa terpengaruh musim, seperti teknologi This is an open access article under the CC-BY SA license pengolahan pakan berupa pembuatan silase dan fermentasi. Pembuatan silase merupakan alternatif teknologi pengolahan pakan untuk mempertahankan nilai nutrisi pada pakan yang akan diberikan ke ternak (Naibaho et al., 2017). Fermentasi sebagai alternatif pengolahan pakan yang praktis apabila diaplikasikan oleh peternak dengan menggunakan bahan pakan sumber karbohidrat yang fermentable (Bata \& Hidayat, 2010; Yanuartono et al., 2017). Teknologi pembuatan silase sudah diketahui Mitra, akan tetapi Mitra belum memiliki pengetahuan dan kemampuan mengimplementasikan pembuatan silase. Oleh karena itu, untuk menyelesaikan permasalahan tersebut, maka perlu upaya penerapan teknologi tepat guna kepada masyarakat dalam membuat pakan silase yang bersumber dari HMT dan limbah pertanian lokal.

Keberhasilan program ini akan meningkatkan ketahanan pakan ternak bagi petani-peternak daerah sub-kritis, meningkatkan tingkat nutrisi pakan ternak ruminansia, dan mengurangi pengeluaran pembelian hijauan pakan ternak di masa puncak kemarau. Selain itu, program ini merupakan salah satu bentuk Tri Dharma Perguruan Tinggi yaitu transfer teknologi sederhana untuk masyarakat pedesaan yang belum terjangkau oleh program pemerintah serupa.

\section{B. PELAKSAAAN DAN METODE}

Tim PKM melibatkan delapan (8) mahasiswa yang sedang menempuh penelitian tugas akhir dalam pelaksanaan tahapan-tahapan PKM.

Metode pelaksanaan kegiatan pengabdian kepada masyarakat dalam skim PKM-UNS 2020 ini dilakukan mengikuti tahapan berikut: 


\section{Persiapan/pelaksanaan internal Tim PKM}

Hal-hal yang harus disiapkan dan dilakukan oleh Tim PKM UNS adalah uji coba pembuatan silase dan teknik fermentasi skala kecil dengan bahan HMT dan limbah pertanian konvensional. Setelah itu dilakukan telaah mendalam terhadap metode/cara kerja agar dapat disusun teknologi pembuatan silase yang sederhana, ekonomis, dan mudah penerapannya bagi masyarakat pedesaan. Tim PKM menyusun buku panduan pelatihan yang disusun dengan diksi, visualisasi dan kualitas cetak yang prima agar kebergunaannya bagi Mitra dalam jangka panjang dan berkesinambungan.

2. Sosialisasi program dan diskusi terfokus (Focus Group Discussion-FGD)

Kegiatan sosialisasi program bertujuan untuk menyamakan langkah dalam pelaksanaan program, peninjauan kembali detail program, dan mengumpulkan kembali usulan-usulan/aspirasi terbaru dari Mitra agar program PKM berjalan lancar dan sukses. Diskusi juga bertujuan untuk memperoleh masukan dari Mitra berkaitan dengan lokasi pelatihan dan jadwal kegiatan. Selain itu juga dilakukan persiapan alat dan bahan yang diperlukan untuk pelaksanaan pelatihan di lokasi Mitra dan pengumpulan informasi terkait ketersediaan alat dan bahan di lokasi sekitar Mitra.

3. Pelatihan pengawetan pakan dan swacoba

Metode yang digunakan adalah pemberian teori dilanjutkan praktek langsung pengawetan pakan ternak dengan teknik silase dan teknik fermentasi dengan kapasitas nyata (aktual).

4. Monitoring produk pengawetan pakan

Pemantauan proses pengawetan pakan dilakukan secara rutin oleh Mitra dan terjadwal oleh Tim PKM. Komunikasi melalui gawai juga sangat mendukung arus informasi antara Mitra dan Tim PKM.

\section{Evaluasi kegiatan}

Evaluasi kegiatan ditujukan untuk menilai tingkat keberhasilan program dan untuk mendiskusikan program selanjutnya sebagai bentuk kontinyuitas program.

\section{HASIL DAN PEMBAHASAN}

Hasil kegiatan PKM berdasarkan tahapan program yang telah dirancang diuraikan sebagai berikut:

1. Persiapan/pelaksanaan internal Tim PKM

Uji coba/ optimasi teknologi sederhana pembuatan silase dan teknik fermentasi dengan bahan baku konvensional (jerami dan batang jagung-tebon) dilakukan dengan skala kecil 8 liter. Fermentor yang digunakan adalah ember bekas es krim yang dapat menjamin kondisi an-aerob dapat tercapai. Bahan tambahan tetes/molasses diperoleh tidak jauh dari lokasi kampus, yaitu dari limbah pengrajin ciu di wilayah Sukoharjo. Dalam uji coba teknik fermentasi, Tim PKM menggunakan stimulator yang dihasilkan dari kegiatan penelitian kolega UNS, yang terbukti dapat memperpendek waktu fermentasi dengan tingkat penerimaan pakan oleh ternak tetap baik. Hal ini juga sebagai wujud kesinambungan aplikasi hasil penelitian perguruan tinggi dalam kegiatan pengabdian kepada masyarakat.

Hasil dari uji coba yang dilakukan Tim PKM selanjutnya dituangkan dalam bentuk booklet/buku saku yang akan digunakan oleh Mitra dalam pelatihan. Buku saku disusun dengan visualisasi yang menarik, diksi dan tata bahasa yang lugas dan kualitas cetak yang prima.

Penyusunan buku saku dengan isi dan kualitas cetak yang bagus ditujukan untuk mempermudah pemahaman dan penerapan di lapangan dan memastikan keberlanjutan kegiatan setelah program PKM-UNS 2020 dinyatakan berakhir. 
2. Sosialisasi program dan diskusi terfokus (Focus Group Discussion-FGD)

Sosialisasi program yang dilakukan membuat seluruh anggota Mitra saling mengenal dengan Tim PKM sehingga meningkatkan kualitas komunikasi Tim PKM dan Mitra yang sebelumnya hanya perwakilan kedua belah pihak saja.

Kondisi pandemi Covid-19 mengakibatkan pelaksanaan kegiatan PKM harus dilakukan penjadwalan ulang. Pada awalnya program disusun agar hasil kegiatan dapat langsung dipergunakan oleh mitra, yaitu mengolah HMT yang melimpah di bulan April-Mei (surplus pakan) dan akan menggunakannya di bulan SeptemberOktober (langka pakan).

Kegiatan pelatihan tidak bisa dilakukan secara daring mengingat Mitra yang merupakan masyarakat pedesaaan perlu sehingga perlu untuk diberikan contoh secara langsung dan disampaikan secara sederhana.

Berdasar diskusi-diskusi yang telah dilakukan oleh Tim PKM dan Mitra, beberapa hal yang menjadi catatan penting adalah: 1)Kegiatan pelatihan dan swa-coba akan dilakukan bila kondisi new-normal pandemi telah berjalan baik tanpa mempertimbangkan kelimpahan HMT dan jerami. Kegiatan dilakukan dengan mengikuti protokol kesehatan. 2).Penyediaan bahan baku pelatihan, akan dilakukan dengan membeli dari daerah lain. 3).Pelatihan dilakukan dalam skala kualitas yang besar/ nyata, dipilih drum biru berkapasitas 120 liter. Pertimbangan lain, untuk menjamin kedap udara, menghindari gangguan keratan tikus dan agar alat pelatihan dapat digunakan lagi sebagai wujud kontinyuitas program.

4).Penyediaan alat pelatihan berupa drum biru, terpal, ember akan diperoleh dari lokasi sekitar Mitra.
5).Pembentukan Kelompok Ternak beserta susunan organisasinya sebagai pengembangan Kelompok Tani yang sudah ada untuk mewadahi kegiatan yang khusus berkaitan dengan ternak.

3. Pelatihan pengawetan pakan dan swacoba

Pelatihan dilakukan dalam 3 sesi utama, yaitu (i) sesi kelas untuk menjelaskan langkah-langkah sesuai dalam buku saku, (ii) sesi praktek langsung dengan pendampingan, dan (iii) sesi swa-coba dengan pendampingan tak langsung.

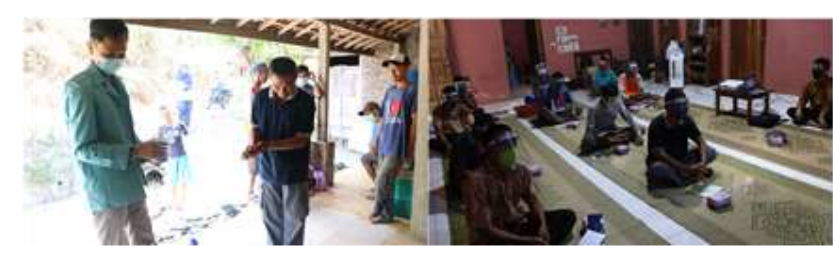

Gambar.4 Pelaksanaan Protokol Kesehatan Covid19 Selama Pelatihan

Kegiatan tatap muka dilakukan dengan mengikuti protokol kesehatan Covid-19, yaitu pengaturan jarak dan penggunaan alat pelindung diri hand sanitizer, cuci tangan dengan sabun, pendeteksi suhu tubuh, face shield serta masker.

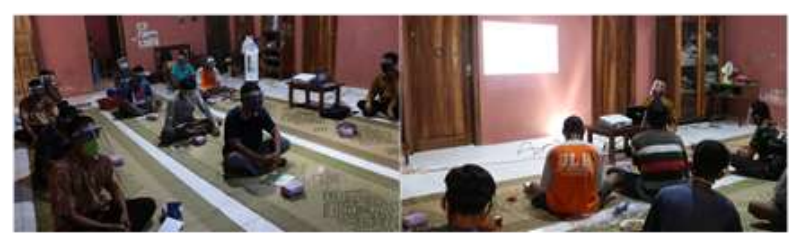

Gambar.5 Pelaksanaan Sesi Kelas dalam Pelatihan Luring dengan Mitra

Pengawetan pakan ternak yang disampaikan oleh Tim PKM dilakukan dengan dua (2) metode, yaitu teknik silase dan teknik fermentasi. Teknik silase dilakukan untuk bahan baku HMT ditujukan untuk memperpanjang umur simpan pakan tanpa kehilangan nutrisi. Sedangkan teknik fermentasi ditujukan untuk meningkatkan 
ketercernaan pakan yang minim nutrisi dengan bantuan mikroorganisme yang akan melapukkan selulosa dan mengurangi lignin yang ditandai dengan keuletan pakan yang menurun (Howard et al., 2002; Zakaria et al., 2013).

\section{Teknik Silase}

Pelatihan teknik silase dilakukan terhadap batang jagung berdasarkan Saun \& Heinrichs (2008) serta Naibaho et al. (2017) dengan beberapa perubahan dan penyesuaian.
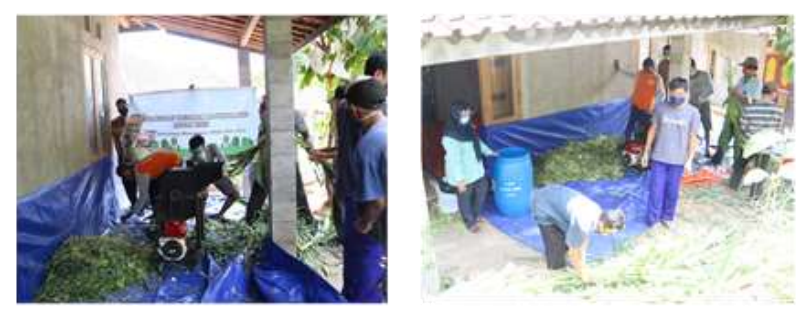

Gambar.6 Pencacahan Batang Jagung untuk Teknik Silase

Persiapan yang dilakukan adalah pelayuan batang jagung dan pemotongan dengan chopper. Kadar air yang tinggi dan embun/air yang terbawa akan berakibat munculnya jamur selama pemeraman. Alihalih terbentuk silase, bahan akan mengalami pembusukan.

Batang jagung yang akan digunakan telah dipotong dari sawah minimal sehari sebelum proses pemeraman dengan terlebih dahulu ditunggu hingga embun menghilang oleh cahaya matahari.

Selanjutnya dilakukan pencampuran bahan tambahan terhadap cacahan batang jagung. Dengan mempertimbangkan kepraktisan pelaksanaan, pencampuran dilakukan langsung dalam drum biru dengan menambahkan bahan secara selang-seling sembari dilakukan pemampatan secara manual. Pemampatan ditujukan agar tidak ada udara yang terjebak dalam bahan sehingga kondisi an-aerob terjadi. Setelah drum terisi penuh maka dilakukan penutupan dan diperkuat. Penguat clamp lebih baik digunakan, tetapi saat itu belum tersedia di lokasi Mitra sehingga Mitra telah menyiapkan bor listrik dan kawat bendrat.

Bahan tambahan yang ditambahkan ke dalam HMT divariasi menjadi tiga (3) jenis, yaitu penggunaan bekatul saja, tetes/ molasses saja, dan campuran bekatulmolasses. Hal ini dilakukan agar Mitra memperoleh pengalaman bahwa bahan tambahan bisa menggunakan bahan-bahan yang tersedia. Mitra mempunyai keinginan untuk mencoba dan berinovasi.

\section{Teknik Fermentasi}

Fermentasi dilakukan terhadap lamen, yaitu batang padi bagian atas sisa perontokan padi. Batang padi didatangkan dari daerah Klaten. Pelaksanaan fermentasi dilakukan dengan menggunakan stimulator produk penelitian UNS. Pelatihan teknik fermentasi berdasarkan Harun \& Geok (2016), Anam et al. (2012) dan Antonius (2010) dengan penyesuaian.

Swa-coba merupakan pendampingan kepada Mitra agar berani mencoba sendiri dan memperhatikan kondisi sekitar sehingga dapat mencari solusi permasalahan terkait sumber pakan berdasar potensi sekitar/ lokal.

4. Monitoring produk pengawetan pakan

Produk fermentasi dapat dipanen setelah tujuh (7) hari proses dan dapat langsung disimpan dalam bentuk tumpukan hingga dapat digunakan sewaktu-waktu.

Hasil fermentasi terhadap lamen menunjukkan lamen lebih mudah diremaspatah yang menandakan kandungan lignin sudah direduksi oleh mikroorganisme dalam stimulator. Penerimaan ternak terhadap pakan fermentasi sangat bagus. Akan tetapi ada sebagian lamen yang ditumbuhi jamur, dan ditengarai karena kelebihan air pelarut yang tidak terserap oleh alas proses fermentasi. Tim PKM menyarankan untuk melakukan fermentasi tanpa alas terpal 
sehingga terpal dapat digunakan untuk memperbanyak kuantitas fermentasi.

Sedangkan produk teknik silase dapat dipanen minimal setelah dua puluh satu (21) hari pemeraman, tetapi bila fermentor sudah dibuka maka pakan harus dihabiskan dalam waktu maksimal tiga (3) hari. Evaluasi kualitas produk silase berdasarkan penampilan fisik, kimia, dan respon ternak sapi yang diberi pakan silase.

Produk silase yang dihasilkan sangat bagus dengan kualifikasi tekstur kering, warna hijau kekuningan, tidak terjadi pembusukan, dan berbau harum-manis. Uji coba pakan dengan memberikannya ke ternak sapi dan kambing memberi respon yang positif sesuai (Khatiwada et al., 2016; Li et al., 2014), bahkan saat di luar waktu pemberian pakan.

5. Evaluasi kegiatan

Evaluasi internal oleh Tim PKM dilakukan setiap selesai agenda kegiatan untuk mengukur tingkat keberhasilan program, memastikan tercapainya target kegiatan, mengidentifikasi permasalahan yang timbul selama program berlangsung, dan menyelesaikan hambatan/ permasalahan yang muncul agar cepat teratasi.

Perubahan perilaku Mitra dievaluasi melalui respon yang muncul selama proses pelatihan maupun setelah rangkaian kegiatan PKM dilaksanakan.

Keberhasilan PKM ini secara komprehensif ditandai dengan:

1). Empat (4) orang anggota Mitra dapat membuat silase dan melakukan teknik fermentasi secara mandiri dengan hasil baik 2). Mitra berani mencoba melakukan pengawetan pakan dengan bahan selain yang dipakai untuk pelatihan, yaitu guguran daun jati, bambu, dan sono yang dikumpulkan dari lingkungan sekitar. 3). Potensi berkurangnya biaya pembelian pakan ternak di masa paceklik pakan di masa mendatang. 4). Keberanian Mitra melakukan inovasi pengembangan stimulator berbahan lokal menggunakan stimulator pelatihan sebagai starter. 5). Keberlanjutan kegiatan walaupun Program kemitraan Masyarakat telah berakhir. 6). Kesinambungan program dalam program $\mathrm{P} 2 \mathrm{M}$ mendatang.

\section{PENUTUP}

\section{Simpulan}

Target PKM-UNS 2020 yang telah dicanangkan dapat dicapai melalui kegiatan dengan baik. Kontinyuitas program juga terbukti telah berlangsung dengan inisiatif Mitra untuk melakukan swa-coba menggunakan bahan baku lokal dan inovasi pengembangan stimulator mandiri. Beberapa temuan selama kegiatan berlangsung akan disusun sebagai program mendatang (2021).

\section{Saran}

Informasi yang komprehensif terkait profil mitra sangat mempengaruhi keberhasilan pelaksanaan kegiatan. Terlepas dari kondisi pandemi Covid-19, pelaksanaan kegiatan harus mempertimbangkan rutinitas Mitra dalam mencari nafkah. Kegiatan pengabdian kepada masyarakat yang Tim PKM usung ditujukan untuk meningkatkan kesejahteraan masyarakat sehingga diharapkan dapat bersinergi dengan tatanan dan mata pencaharian pokok.

\section{Ucapan Terima Kasih}

Tim PKM menyampaikan ucapan terima kasih yang sebesar-besarnya kepada LPPM UNS atas pendanaan kegiatan pengabdian kepada masyarakat ini melalui Program Kemitraan Masyarakat (PKM UNS) 2020 sesuai project number 00230175052292020 dengan Kontrak Pengabdian Nomor: 453/UN27.21/PN/2020 tanggal 23 April 2020. 
Tim PKM juga menyampaikan terima kasih kepada mahasiswa yang terlibat dalam seluruh kegiatan.

\section{E. DAFTAR PUSTAKA}

Amin, M., Hasan, S. D., Yanuarianto, O. \& Iqbal, M. (2015). Pengaruh Lama Fermentasi Terhadap Kualitas Jerami Padi Amoniasi yang Ditambah Probiotik Bacillus Sp. Jurnal Ilmu Dan Teknologi Peternakan Indonesia, 1(1), 11-17.

Anam, N. K., Pujaningsih, R. I. \& Prasetiyono, B. W. H. E. (2012). Kadar Neutral Detergent Fiber dan Acid Detergent Fiber pada Jerami Padi dan Jerami Jagung yang Difermentasi Isi Rumen Kerbau. Animal Agriculture Journal, 1(2), 352-361.

Antonius. (2010). Pengaruh Pemberian Jerami Padi Terfermentasi terhadap Palatabilitas Kecernaan Serat Dan Digestible Energy Ransum Sapi. Seminar Nasional Teknologi Peternakan Dan Veteriner 2010, 3 4(Agustus), 224-228.

Bata, M. (2008). Pengaruh Molases pada Amoniasi Jerami Padi Menggunakan Urea Terhadap Kecernaan Bahan Kering dan Bahan Organik in Vitro. Agripet, 8(2), 15-20.

Bata, M. \& Hidayat, N. (2010). Penambahan Molases untuk Meningkatkan Kualitas Amoniasi Jerami Padi dan Pengaruhnya terhadap Produk Fermentasi Rumen Secara In-Vitro. Agripet, 10(2), 27-33.

Harun, S. \& Geok, S. K. (2016). Effect of Sodium Hydroxide Pretreatment on Rice Straw Composition. Journal of Science and Technology, 9(21), 1-9. https://doi.org/10.17485/ijst/2016/v9i2
$1 / 95245$

Howard, R. L., Abotsi, E., L, J. V. R. E. \& Howard, S. (2002). Lignocellulose biotechnology: Issues of bioconversion and enzyme production. African Journal of Biotechnology, 2(12), 602619.

https://doi.org/10.5897/AJB2003.0001115

Khatiwada, P., Ahmed, J., Sohag, M. H., Islam, K. \& Azad, A. K. (2016). Isolation, Screening and Characterization of Cellulase Producing Bacterial Isolates from Municipal Solid Wastes and Rice Straw Wastes. J Bioprocess Biotech, 6(4), 1$5 . \quad$ https://doi.org/10.4172/21559821.1000280

Lamid, M., Nyoman, N., Puspaningsih, T. \& Mangkoedihardjo, S. (2013). Addition of Lignocellulolytic Enzymes into Rice Straw Improves in Vitro Rumen Fermentation Products. Journal of Applied Environmental and Biological Sciences Www.Textroad.Com Appl. Environ. Biol. Sci., 3(9), 166-171.

Li, H. Y., Xu, L., Liu, W. J., Fang, M. Q. \& Wang, N. (2014). Assessment of the Nutritive Value of Whole Corn Stover and Its Morphological Fractions. Asian Australas J. Anim. Sci, 27(2), 194-200.

Naibaho, T., Despal \& Permana, I. G. (2017). Perbandingan Silase Ransum Komplit Berbasis Jabon dan Jerami untuk Meningkatkan Ketersediaan Pakan Sapi Perah Berkualitas Secara Berkesinambungan. Buletin Makanan Ternak, 104(2), 12-20.

Saun, R. \& Heinrichs, J. (2008). Troubleshooting Silage Problems: How to Identify Potential Problemtle. Proceedings of the Mid-Atlantic 
Conference, 26-28.

Yanuartono, Purnamaningsih, H., Indarjulianto, S. \& Nururrozi, A. (2017). Potensi jerami sebagai pakan ternak ruminansia. Jurnal Ilmu-Ilmu Peternakan, 27(1), 40-62.

Zakaria, Y., Novita, C. I. \& Samadi, S. (2013). Efektivitas Fermentasi dengan Sumber Substrat yang Berbeda Terhadap Kualitas Jerami Padi. Jurnal Agripet, 13(1), 22-25. https://doi.org/10.17969/agripet.v13i1.5 48. 